\title{
REPORT ON THE ANNUAL CONFERENCE OF THE INTERNATIONAL MEDIA MANAGEMENT ACADEMIC ASSOCIATION (IMMAA) IN 2015
}

\section{ОТЧЕТ О ЕЖЕГОДНОЙ КОНФЕРЕНЦИИ МЕЖДУНАРОДНОЙ АССОЦИАЦИИ ИССЛЕДОВАТЕЛЕЙ МЕДИАМЕНЕДЖМЕНТА (ІММАА) В 2015 ГОДУ}

\begin{abstract}
Anna A. Gladkova, PhD in Philology, Senior Researcher, Chair of Media Theory and Media Economics, Faculty of Journalism, Lomonosov Moscow State University, Moscow, Russia gladkova_a@list.ru

Анна Александровна Гладкова, кандидат филологических наук, старший научный сотрудник, кафедра теории и экономики СМИ, факультет журналистики, Московский государственный университет имени М. В. Ломоносова, Москва, Россия gladkova_a@list.ru
\end{abstract}

On September 17-18, 2015 the Faculty of Journalism, Lomonosov Moscow State University hosted the annual conference of IMMAA organization. IMMAA (International Media Management Academic Association) is an international academic platform, which unites researchers of media economics and media management from different parts of the world. The main goal of IMMAA network is to develop international research on media management by conducting original research projects and holding international conferences and workshops centered around issues of media economics and media management. In 2015, IMMAA's annual conference was organized under the umbrella of the Seventh 
International Media Readings in Moscow "Mass Media and Communications-2015" with support from the Federal Agency for Press and Mass Communications of the Russian Federation.

During the two days of the conference scholars from more than fifteen countries (Portugal, Germany, France, Austria, Russia, China, Republic of Korea, USA and many others) discussed the state of global and national media markets, the issues of media entrepreneurship in the age of digitalization, transformation of the advertising markets in the world, current development of public media and media policy in different countries.

The conference included several plenary meetings, a series of round table discussions, a workshop, a poster session, and a number of thematic sessions in both English and Russian languages. During the thematic session devoted to the media systems in BRICS countries, researchers outlined main similarities and differences between media in these countries and compared them to some Western media systems. The session on the development of social media in the world brought together representatives of media companies and scholars, who shared their thoughts on the role of new media in journalistic practices, and discussed the effects new media currently have on media business and media consumption.

During poster session, young researchers and $\mathrm{PhD}$ students presented the results of their research work and interacted with other conference participants while answering their questions and discussing their latest research findings. The most popular issue to cover during this session turned out to be the efficiency and specifics of different business models at the national media markets today.

Along with an intensive academic program, the conference offered its participants an opportunity to attend a number of cultural events, including the guided tour of Red Square and Arbat street, and a visit to "Russia Today" TV channel. The managing director of 
"Russia Today" Aleksey Nikolov discussed the information policy of the channel and shared his view of the importance of journalistic ethics in everyday media practice.

Last but not least, IMMAA's board gathered to discuss the next annual conference, which is scheduled for October 27-30, 2016. The conference will be hosted by the School of Media and Communication, Korea University with support from Korea Media Management Association. In addition, IMMAA's board members discussed the conference in Moscow and spoke about possible ways to broaden IMMAA's international outreach in the future.

Closing the conference, IMMAA's chairman Professor Paulo Faustino (Porto University, Portugal) extended thanks to the Faculty of Journalism. The Dean, Professor Elena Vartanova mentioned that the conference has become an important event for Russian media studies, which gives Russian and foreign scholars an opportunity to discuss the future of mass communications and journalism in different parts of the world. 